\title{
RAZGLEDI
}

\section{RAKIŠKI STRŽEN: HIDROGEOGRAFSKE ZNAČILNOSTI IN OCENA KAKOVOSTNEGA STANJA}

\author{
AVTORJA \\ dr. Gregor Kovačič \\ Univerza na Primorskem, Fakulteta za humanistične študije in Znanstveno-raziskovalno središče Univerze \\ na Primorskem, Titov trg 5, SI - 6000 Koper, Slovenija; gregor.kovacic@fhs.upr.si
}

\section{Tina Rupnik}

Rakitnik 36, SI - 6258 Prestranek, Slovenija; tinarupnik2@gmail.com

DOI: $10.3986 / G V 87103$

UDK: 911.2:502.51(282)(497.471)

COBISS: 1.01

\section{IZVLEČEK}

\section{Rakiški stržen: hidrogeografske značilnosti in ocena kakovostnega stanja}

Članek obravnava hidrogeografske značilnosti Rakiškega stržena in njegovo kakovostno stanje. Predstavljeni so rezultati meritev fizikalno-kemijskih parametrov, opravljeni s preprostim prenosnim laboratorijem na treh lokacijah v obdobju med oktobrom 2013 in junijem 2014, ki kažejo na slabšo kakovost potoka ob nizkih vodah. Kobremenjevanju najbolj prispevajo prečiščene odpadne vode iz čistilne naprave v Postojni ter neprečiščene odpadne vode iz Rakitnika. Kakovost občasnih kraških izvirov, ki napajajo potok ob visokih vodah, je boljša, saj razen nitratov druga onesnažila niso bila izmerjena. Pretok Rakiškega stržena v daljšem obdobju smo ocenili na 1,18, v izjemno namočenem hidrološkem letu 2014 pa na 2,5 $\mathrm{m}^{3} / \mathrm{s}$.

\section{KLJUČNE BESEDE}

Rakiški stržen, Pivka, Centralna čistilna naprava Postojna, kakovostno stanje vode, onesnaževanje, poplave

\section{ABSTRACT}

\section{The Rakiški Stržen brook: hydrogeographic characteristics and water quality assessment}

The article deals with hydrogeographic characteristics and water quality assessment of the Rakiški Stržen brook. Results of the measurements of physico-chemical parameters, carried out by using portable water analysis test kits in the period from mid-October 2013 to mid-June 2014 at three sampling points, are presented. The results show, that quality of the brook is low at low waters. Treated wastewaters from the Central Wastewater Treatment Plant Postojna and untreated wastewaters from the Rakitnik village contribute the greatest part of the burdening of the brook. The quality of the temporal karst springs that recharge the brook at high waters is much better. With an exception of nitrates, the presence of other pollutants in the springs was not determined. We estimated the mean discharge of the Rakiški Stržen for a longer period at $1.18 \mathrm{~m}^{3} / \mathrm{s}$. For the extraordinary wet hydrological year 2014, the discharge was estimated at $2.5 \mathrm{~m}^{3} / \mathrm{s}$.

\section{KEY WORDS}

Rakiški Stržen brook, Pivka basin, Central Wastewater Treatment Plant Postojna, water quality condition, pollution, floods

Uredništvo je prispevek prejelo 4. marca 2015. 


\section{Uvod}

Rakiški stržen je zadnji desni pritok Pivke pred njenim ponorom v Postojnsko jamo. Potok se napaja iz več manjših kraških izvirov, njihovo vodozbirno zaledje so Javorniki in Zgornja Pivka, kar dokazujejo rezultati sledenj podzemnih voda (Habič 1989; Kogovšek 1999; Kogovšek s sodelavci 1999). Manjši, površinski del porečja Rakiškega stržena, je razvit na slabo prepustnih kamninah, od koder se v potok iztekajo tudi prečiščene odpadne vode iz Centralne čistilne naprave Postojna (v nadaljevanju CČN), kar zelo vpliva na njegovo kakovostno stanje.

Rakiški stržen je primer manjšega vodotoka z izrazitim kolebanjem pretokov, ki je zelo obremenjen z onesnaževanjem. Pokrajinsko občutljivost potoka povečuje njegovo pretežno kraško zaledje, ki je dokaj obsežno, zaradi česar je njegova samočistilna sposobnost majhna. Z raziskavo smo želeli osvetliti problem prekomernega obremenjevanja Rakiškega stržena ter preučiti, ali je obstoječe upravljanje $\mathrm{z}$ vodami $\mathrm{v}$ njegovem porečju zadovoljivo za zagotavljanje ustreznega kakovostnega stanja potoka.

$\mathrm{V}$ prispevku predstavljamo kakovostno stanje potoka in vire obremenjevanja, za katere smo poskušali oceniti prispevek k celokupnemu onesnaževanju vodotoka. Namen prispevka sta tudi podroben opis in razlaga hidrogeografskih značilnosti Rakiškega stržena, ki do sedaj niso bile celovito predstavljene in do katerih smo prišli tudi s pomočjo opazovanj in meritev v hidrološkem letu 2014.

\section{Metodologija}

Terensko delo je obsegalo meritve kakovostnega stanja vode in zajem vzorcev za kasnejše fizikalno-kemijske analize na treh merilnih mestih (slika 1). Meritve, teh je bilo 46, smo na približno štirinajst dni opravljali ob različnih vodnih stanjih od sredine oktobra 2013 do sredine junija 2014. Prvo merilno mesto je bilo na občasnem kraškem izviru Fužina, južno od Stare vasi (slika 3). Štirikrat, v času ko je bil izvir presušen, smo vzorčenje in ostale meritve opravili v obzidanem koritu s pipo (stalno tekoča voda), ki leži približno 170 m severno od izvira, in je nekdaj služilo kot vodno zajetje za Staro vas. Drugo merilno mesto je bilo na sotočju Rakiškega stržena s pritokom, ki zbira površinske vode z območja Postojne, v katerega je speljan tudi iztok iz CČN (slika 8). Tretje merilno mesto je bilo v strugi Rakiškega stržena v Rakitniku, sto metrov zahodno od mostu in slab kilometer pred njegovim izlivom v Pivko. Ob ojezeritvi območja meritve na drugem in tretjem merilnem mestu niso bile mogoče, zato smo ob takšnih razmerah le-te opravili na robu ojezerjene površine.

Z oksimetrom (Oxi 315i DurOx 325) smo merili temperaturo vode, vsebnost raztopljenega kisika $\mathrm{v}$ vodi $\mathrm{v} \mathrm{mg} / \mathrm{l}$ ter nasičenost vode $\mathrm{s}$ kisikom $\mathrm{v}$ odstotkih. Vzorce vode smo analizirali s pomočjo prenosnega laboratorija Macherey-Nagel visocolor ECO Analysenkoffer. Določali smo celokupno in karbonatno trdoto vode, $\mathrm{pH}$, vsebnost nitratov, nitritov, amonijevih ionov in fosfatov. Kakovost potoka smo opredelili na podlagi mejnih vrednosti parametrov, določenih v Uredbi o stanju površinskih voda (2009) ter po Urbaniču in Tomanu (2003) ter Vovk Koržetovi in Bricelju (2004), ki podajajo mejne vrednosti parametrov v odvisnosti od vzroka onesnaženja. Čeprav Rakiški stržen ni vir pitne vode, smo se zaradi njegove lege v hidrografskem zaledju izvira Vipave, ki je zajet za vodooskrbo, odločili izmerjene koncentracije parametrov primerjati tudi z mejnimi vrednostmi iz Pravilnika o pitni vodi (2004-2009). V primerjavi z zgoraj omenjeno uredbo, ki opredeljuje zgolj mejne vrednosti za nitrate, slednji opredeljuje mejne vrednosti za večino merjenih parametrov. Rezultate meritev smo primerjali tudi $\mathrm{z}$ razpoložljivimi podatki o merjenih parametrih kakovosti vode na iztoku iz CČN, ki smo jih pridobili od upravljavca, podjetja Kovod d. o. o. (Poročilo o obratovalnem monitoringu ... 2015).

Vir hidroloških in padavinskih podatkov o povprečnih mesečnih pretokih Pivke na vodomerni postaji Prestranek v obdobju 1961-2010, dnevnih pretokih Pivke na vodomernih postajah Prestranek in Zalog v obdobju 22.2.1974-31.12.1977 in dnevnih pretokih Pivke (Prestranek) v obdobju 1.10.2013-30.6.2014 
ter povprečnih mesečnih padavinah v obdobju 1961-2010 na klimatološki postaji Postojna in polurnih padavinah na samodejni meteorološki postaji Postojna v obdobju 1.10.2013-30.6.2014 je bila Agencija Republike Slovenije za okolje (Podatki o dnevnih ... 2004a; Podatki o polurnih ... 2014b).

Pod mostom v Rakitniku smo v strugo Rakiškega stržena ob nizkem vodostaju 16. 10.2013 namestili samodejni merilnik (Onset HOBO T in $h$ Data Logger), ki je v polurnih intervalih beležil vodostaj in temperaturo potoka (slika 2). Podatki o pretoku Pivke v Prestranku kažejo, da je začetek meritev sovpadal s pričetkom hidrološkega leta 2014. Hidrološke meritve so trajale 251 dni in smo jih sklenili pred iztekom hidrološkega leta, 23.6.2014, v času, ko je pretok Stržena še upadal in je bil njegov vodostaj samo nekaj centimetrov nad ravnijo merilnika. S pomočjo izmerjenih podatkov smo opredelili pretočne značilnosti Rakiškega stržena.

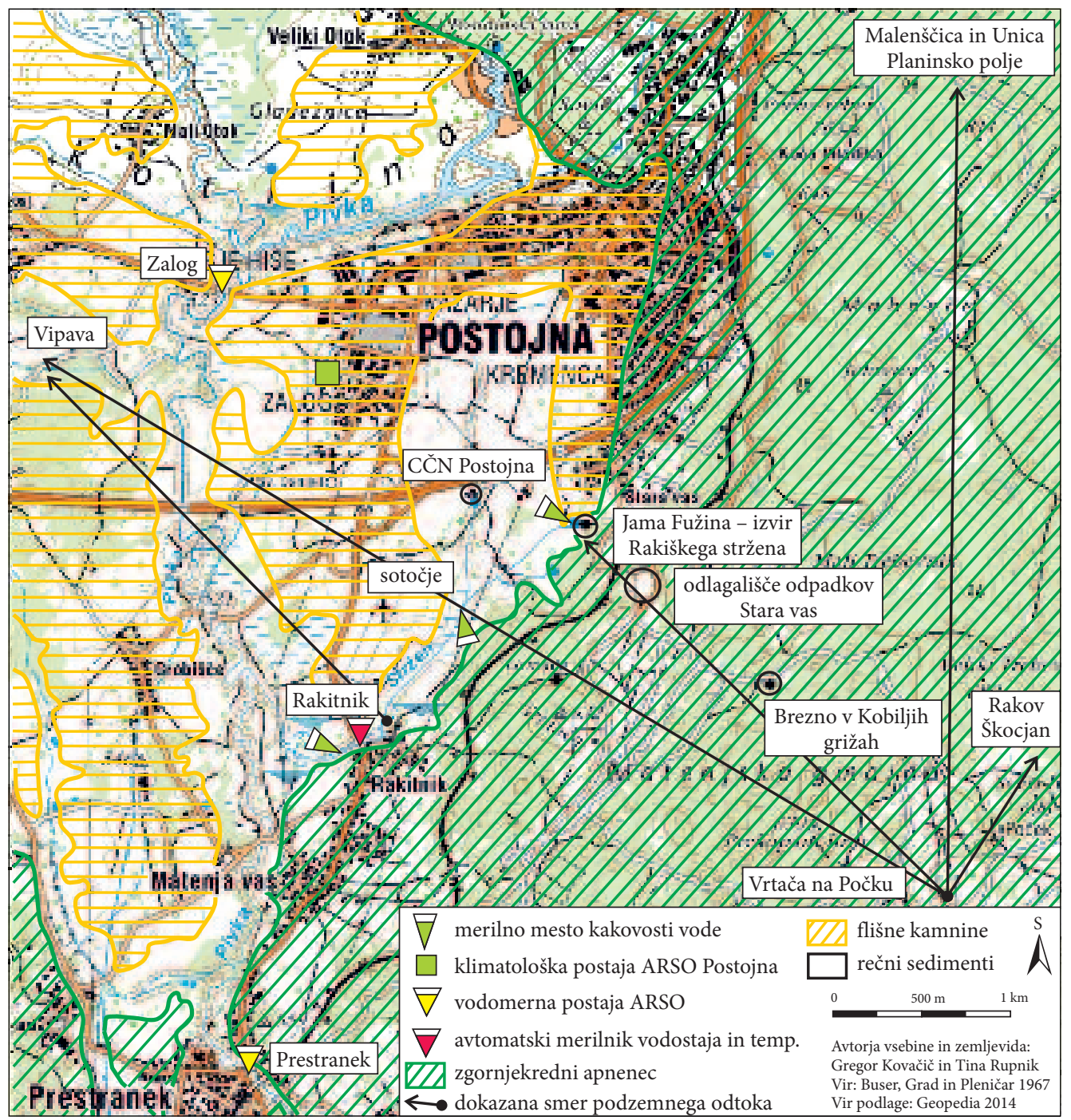

Slika 1: Porečje Rakiškega stržena z geološko zgradbo ter prikazom lokacij merilnih mest kakovosti vode. 


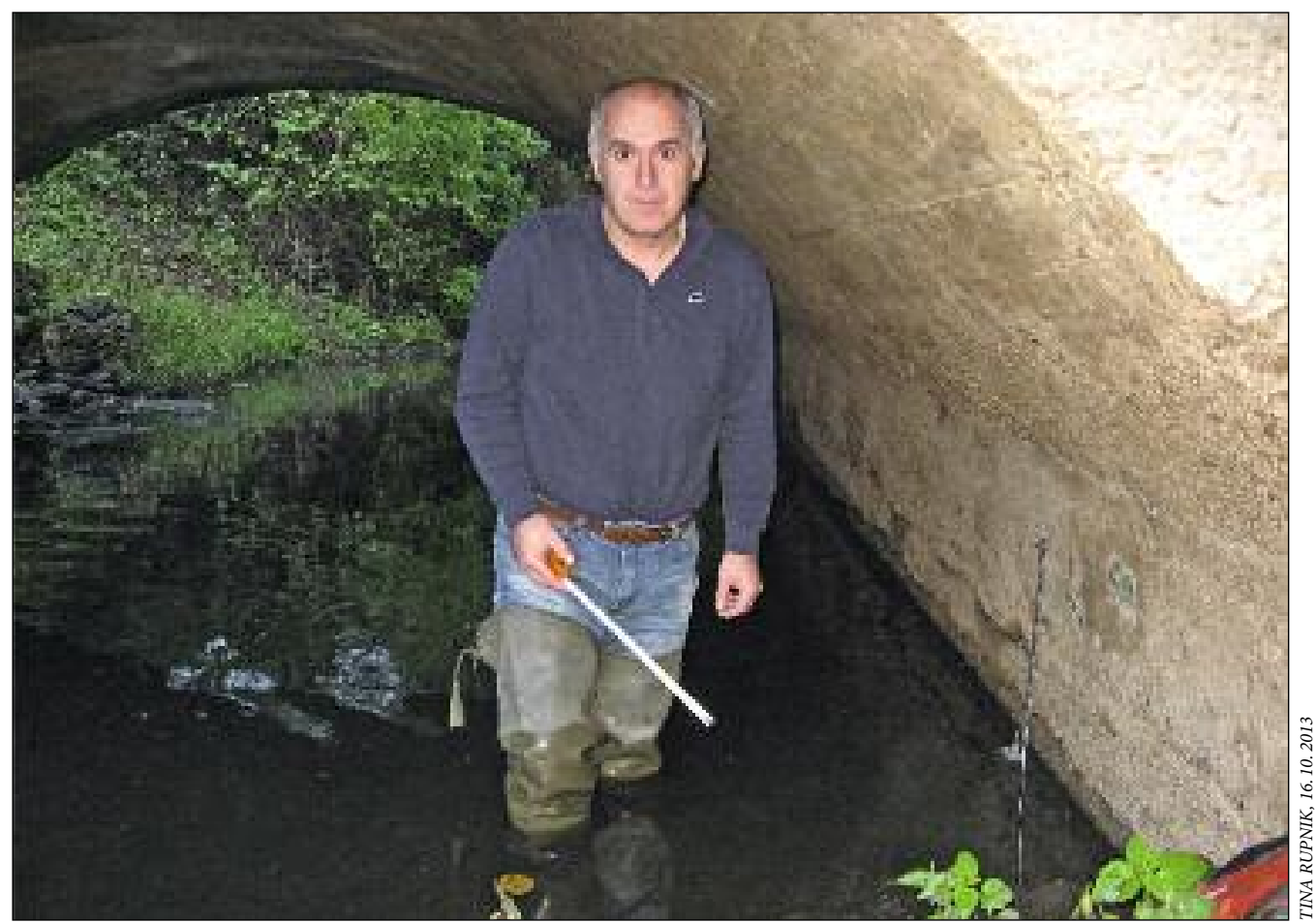

Slika 2: Namestitev samodejnega merilnika v strugi Rakiškega stržena pod mostom v Rakitniku.

\section{Hidrogeografske značilnosti Rakiškega stržena in njegovega porečja}

Rakiški stržen (do nedavnega Stržen; Ferko 2014) je približno 3 km dolg in v celoti reguliran desni pritok Pivke, ki se ob visokih vodah napaja iz kraških izvirov na severozahodnem robu Javornikov med Staro vasjo in Rakitnikom (slika 1). Največji med njimi je jama Fužina (tudi Velika Fužina; slika 3). Po različnih ocenah njegov največji pretok doseže 2-2,6 m³ $/ \mathrm{s}$ (Gospodarič, Habe in Habič 1968; Petrič in Šebela 2005). Ko pa dotok iz kraškega zaledja preneha, hranijo potok zgolj površinske vode $s$ fliša in rečnih naplavin južnega dela Postojne ter mestne odplake, ki se prečiščujejo na CČN (Habič 1989). Površinski del porečja obsega približno $1,75 \mathrm{~km}^{2}$, skupna dolžina stalnih in občasnih površinskih tokov ter melioracijskih jarkov je $8,2 \mathrm{~km}$, gostota vodnih tokov je $4,64 \mathrm{~km} / \mathrm{km}^{2}$, medtem ko je ta (upoštevajoč tudi občasne tokove) v celotnem porečju Pivke $519 \mathrm{~m} / \mathrm{km}^{2}$ (Kranjc 1985). Površina vodozbirnega zaledja občasnih kraških izvirov, ki ob visokih vodah bruhajo na stiku dobro prepustnih apnencev s slabše prepustnimi flišnimi kamninami, ni poznana. S pomočjo členov vodne bilance, ki obsegajo posredno izračunan povprečni pretok Stržena (glej naslednje poglavje), povprečne padavine na klimatološki postaji Postojna v obdobju 1981-2010 (slika 5; Podatki o polurnih ... 2014b) in povprečno izhlapevanje v njegovem zaledju v obdobju 1971-2000 (Raster realne evapotranspiracije ... 2008), ocenjujemo, da se zaledje razteza na približno $40 \mathrm{~km}^{2}$.

Poenostavljeno kamninsko zgradbo obravnavanega območja prikazuje slika 1. Struga Rakiškega stržena se tako kot Pivka in ostali njeni pritoki vije po ilovnati naplavini (poplavni, po večini tudi zamočvirjen svet). V njej je izoblikovan vodonosnik z medzrnsko poroznostjo. Severni krak Rakiškega stržena zbira vodo s flišnih kamnin, ki gradijo Spodnjo Pivko. Iz flišnih kamnin so zgrajena tudi nizka razvodna 

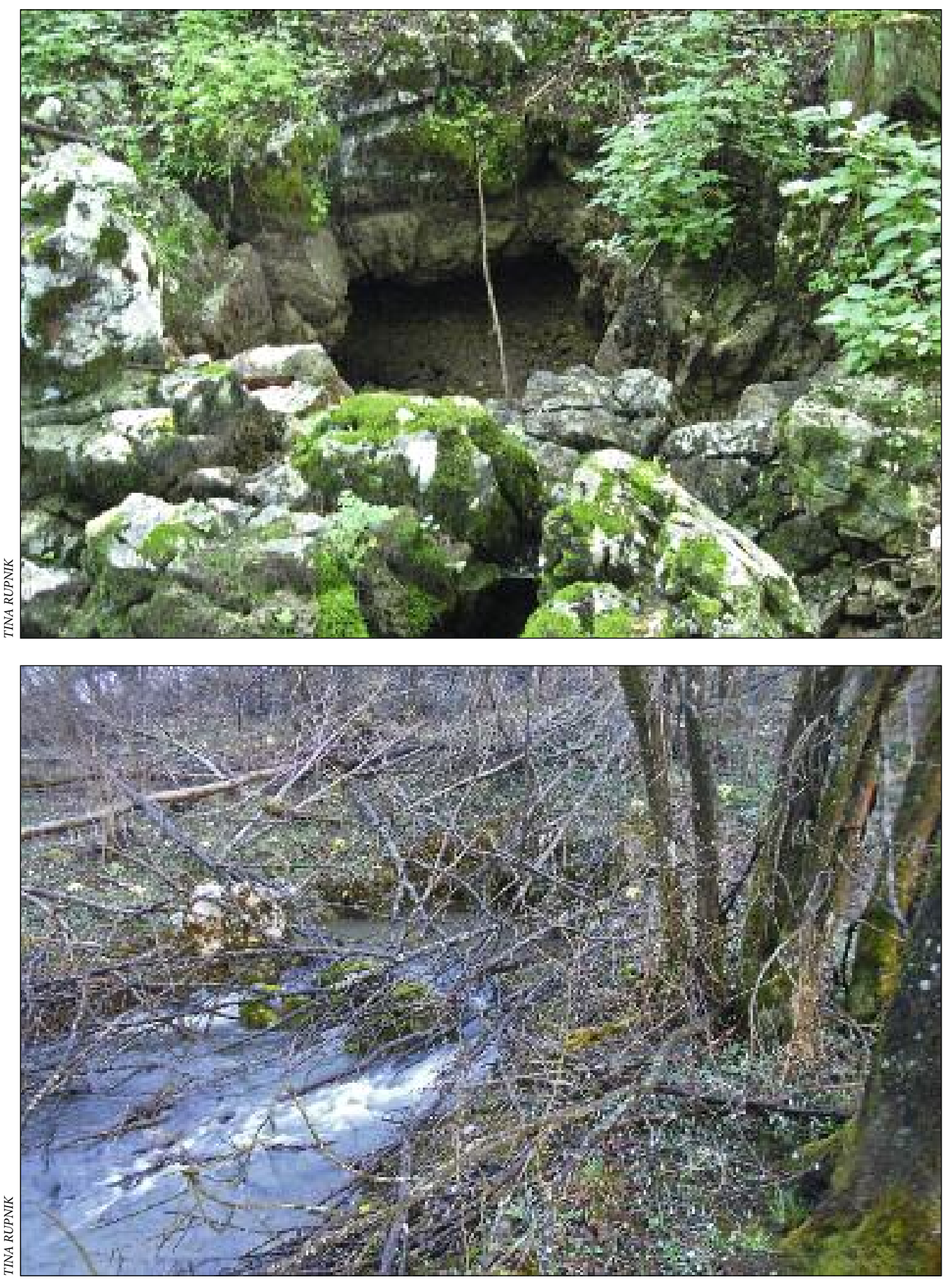

Slika 3: Kraški izvir Fužina ob suši (30. 8. 2013) in visokih vodah (26. 3. 2015). 
slemena, ki ločujejo doline številnih slabo vodnatih (večino občasnih) levih pritokov Pivke do njenega ponora v Postojnski jami (Buser, Grad in Pleničar 1967; Pleničar 1970; Gospodarič 1989). V flišnih kamninah je oblikovan plitev vodonosnik z medzrnsko in razpoklinsko poroznostjo majhne izdatnosti. Zaledje občasnih kraških izvirov, ki se razteza na območju zahodnih Javornikov, gradita zelo zakrasela debeloskladnat rudistni apnenec in skladnat do neskladnat bel rudistni apnenec z roženci (Buser, Grad in Pleničar 1967; Pleničar 1970; Gospodarič 1989; Rižnar 1997). V njiju je oblikovan dobro prepusten vodonosnik s kraško razpoklinsko poroznostjo. Skladi apnencev na zahodnem robu Javornikov upadajo proti zahodu z naklonom do $20^{\circ}$ (Petrič in Šebela 2005). Izvirsko območje prečkata tudi dva preloma (Petrič in Šebela 2005), ki sta verjetno vplivala na nastanek nekaterih izvirov. Zahodno od Stare vasi se med apnenci in flišnimi kamninami nahaja ozek pas breče s kosi paleocenskega apnenca in vložki konglomerata in laporja (ni prikazano na sliki 1) (Rižnar 1997; Petrič in Šebela 2005).

Gladina kraške podtalnice na zahodnem obrobju Javornikov je običajno $10-20 \mathrm{~m}$ pod prelivnim robom doline Pivke (Habič 1989). V vrtini pri jami Fužina niha 10 (nadmorska višina 512,81-522,59 m), v vrtini v Breznu pri Kobiljih grižah pa 15 metrov (nadmorska višina 514,64-529,44 m) in je stalno višja od gladine vode v prvi vrtini (Habič 1989). Danes sta vrtini zamašeni (Petrič in Kogovšek 2005). Naklon gladine kraške podtalnice v vrtinah kaže na podzemni vodni tok proti zahodnemu robu Javornikov, kar je bilo dokazano tudi s sledilnimi poizkusi. 9.8. 1988 so v požiralnik v strugi Pivke v Trnju ob majhnem pretoku injicirali uranin, ki se je po dobrih petih dneh pojavil tudi v Rakiškem strženu (Habič 1989). 10.6. 1997 so v vrtačo na Počku (slika 1) injicirali uranin, ki se je po šestih dneh pojavil na izviru Fužina (Kogovšek 1999; Kogovšek s sodelavci 1999; Kogovšek in Petrič 2004). Tudi Rakiški stržen je bil sleden dvakrat. Prvič ob nizkih vodah 23.2. 1982, ko so v požiralnik (grez) v njegovi strugi pri Rakitniku injicirali uranin, vendar sledila v opazovanih izvirih (med njimi ni bilo Vipave) niso nikjer zaznali (Habič 1989). Sledenje so ponovili 9. 8.1988 ob majhnem pretoku (101/s), ko so v požiralnik (grez) injicirali rodamin. Takrat je bila dokazana podzemna vodna zveza z izviri Vipave, zato Habič $(1989,239)$ območje Spodnje Pivke imenuje »cona skritega krasa s podzemeljskim odtokom Pivke proti Vipavi«. Sledilo

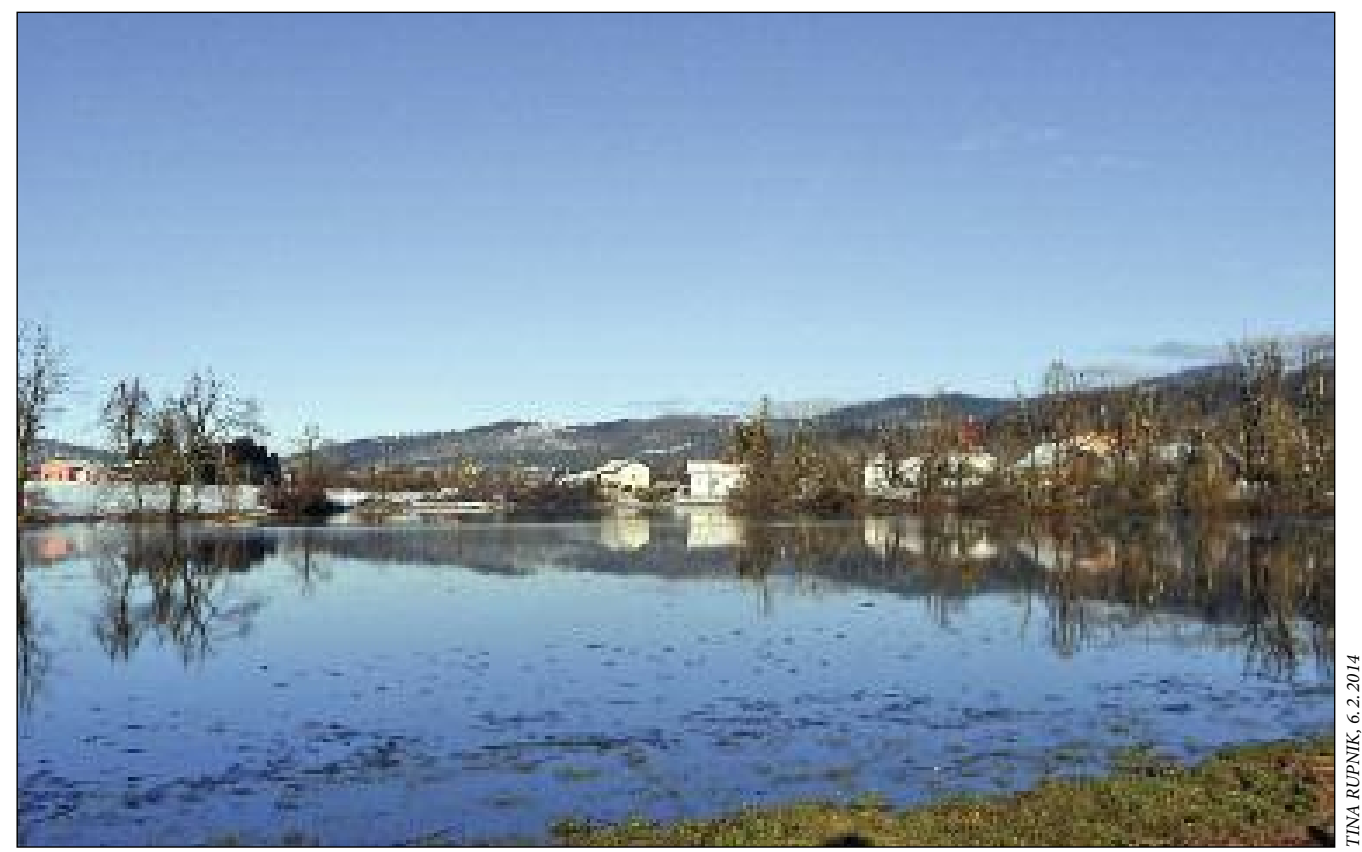

Slika 4: Ojezerjeno območje med Rakitnikom in izlivom v Pivko. 
se je takrat pojavilo tudi na izvirih Timave, vendar je bilo opazovanj premalo, da bi lahko povezavo zanesljivo potrdili (Petrič in Kogovšek 2005). Rezultati zgornjih sledenj dokazujejo podzemeljsko bifurkacijo med jadranskim in črnomorskim povodjem $\mathrm{v}$ zahodnem delu Javornikov, saj del voda stalno odteka proti Vipavi, del pa v izvire Unice na Planinskem polju. Poleg podzemeljske pa obstaja tudi površinska bifurkacija, saj se ob višjih vodostajih del javorniških voda (tudi skozi občasne izvire Rakiškega stržena) preliva v površinsko Pivko (Habič 1989; Kogovšek 1999; Kogovšek s sodelavci 1999; Kogovšek in Petrič 2004).

Dolina Rakiškega stržena je široka in plitva. Strmec potoka od glavnega občasnega izvira Fužina (nadmorska višina $522 \mathrm{~m}$ ) do izliva v Pivko (nadmorska višina $519 \mathrm{~m}$; temeljni topografski načrt $1: 5000$ (1978)) je majhen (1,07\%o), zato je potok pred regulacijami vijugal $v$ številnih okljukih po poplavni ravnici, kar dokazujejo starejši zemljevidi (Rajšp in Ficko 1997). Strmec je nekoliko večji (3,5\%o), če upoštevamo najvišje dele porečja potoka na flišnih kamninah. Z regulacijami potoka, prve večje so v porečju Pivke izvedli v letu 1936 (Kranjc 1985), so okljuke odpravili ter strugo Rakiškega stržena izravnali od izvira do izliva v Pivko (Šabec 2013). Regulacije so se med Staro vasjo in Rakitnikom izvajale tudi v letu 1984 in so bile povezane z gradnjo CČN, ki je z obratovanjem začela leto kasneje (Habič 1989).

Majhen strmec povzroča zastajanje vode (zamočvirjena tla) ter poplave. Poplave Rakiškega stržena so redne, običajno se pojavijo ob obilnejšem jesenskem deževju, ko so aktivni občasni kraški izviri. Poplavno območje se razteza od izvira do izliva in je razdeljeno na dva dela (slika 4). Prvi del je med izvirom in Rakitnikom, drugi pa na ravnini med Rakitnikom in izlivom potoka v Pivko, kjer prihaja do združitve poplav Pivke in Rakiškega stržena. Ob največjih vodostajih je ojezerjeno zemljišče veliko približno 70 ha, zato je to območje od leta 2014 vpisano v Register zemljepisnih imen z lastnim imenom Rakiško jezero (Ferko 2014). Poplave ne povzročajo škode, saj so se jim prebivalci ustrezno prilagodili. Trajanje ojezeritve je pogojeno tudi z vodnatostjo Pivke, ki s svojim tokom zajezi odtok Rakiškega stržena in s tem povzroči širjenje poplave ob njegovi strugi navzgor.

Še eno posebnost je treba omeniti. Hidrološka funkcija vzhodnega roba doline Rakiškega stržena, na meji med apnenci in naplavinami, je dvojna. Ob visokih vodah so tu aktivni kraški izviri, ravno tako pa je to tudi požiralni rob, saj so ob nizkih vodah vse od izvira Fužina do Rakitnika aktivni ponori. Habič (1985) navaja, da so v enega od izvirov, ki je prevzel vlogo požiralnika, v času že omenjenih regulacij Rakiškega stržena v letu 1984, speljali odtok postojnskih odplak. Pri Rakitniku Rakiški stržen na levem bregu ponika $\mathrm{v}$ polkrožnih zatrepih, $\mathrm{v}$ njegovi strugi pa $\mathrm{v}$ mladih naplavinah, ki prekrivajo zakrasele apnence, občasno nastajajo tudi grezi (Habič 1985; 1989). V nekaterih od njih so bili opravljeni že omenjeni sledilni poizkusi.

\subsection{Hidrološka opazovanja in meritve ter izračuni pretokov Rakiškega stržena}

$\mathrm{Na}$ Rakiškem strženu se pretoki ne merijo, zato smo njihove vrednosti ocenili posredno, s pomočjo razpoložljivih podatkov o dnevnih pretokih Pivke na vodomernih postajah Prestranek (slika 5) in Zalog v obdobju 22.2. 1974-31. 12. 1977. Uporabili smo dve predpostavki. Prva, ki velja za zgornje obdobje in hidrološko leto 2014, je, da je pretok Pivke pri Zalogu seštevek pretokov Pivke v Prestranku in Rakiškega stržena. To ne velja v celoti, saj v Pivko od Prestranka dolvodno z leve pritekajo še nekateri drugi potoki, ki zbirajo vode s flišnih kamnin, kot denimo Sušica, po Habičevem (1989) mnenju pa se del vode Pivke tudi izgublja v njeni strugi in odteka v izvire Vipave. Druga predpostavka je, da smo za vodomerno postajo Prestranek, na podlagi katere smo s pomočjo regresijske funkcije drugega reda izračunali pretok Pivke na vodomerni postaji Zalog in Rakiškega stržena v preučevanem obdobju hidrološkega leta 2014, za obdobje 22.2. 1974-31.12. 1977 privzeli pretočno krivuljo, ki velja danes. Izračuni so namreč pokazali povsem nerealne največje pretoke Pivke pri Zalogu $\left(\mathrm{Q}_{\max }>370 \mathrm{~m}^{3} / \mathrm{s}\right) \mathrm{v}$ hidrološkem letu 2014 ob uporabi dejanskih pretokov Pivke (Prestranek) v obdobju 22. 2. 1974-31. 12. 1977.

Povprečni pretok Rakiškega stržena v obdobju 22.2. 1974-31.12.1977 je bil $1,18 \mathrm{~m}^{3} / \mathrm{s}\left(\mathrm{Q}_{\max }=27,30 \mathrm{~m}^{3} / \mathrm{s}\right.$; $\mathrm{Q}_{\min }=0 \mathrm{~m}^{3} / \mathrm{s} ; \mathrm{Q}_{95}=5,43 \mathrm{~m}^{3} / \mathrm{s}$ in $\mathrm{Q}_{5}=0 \mathrm{~m}^{3} / \mathrm{s}$ ), pretok pa kaže veliko spremenljivost, saj je standardni 


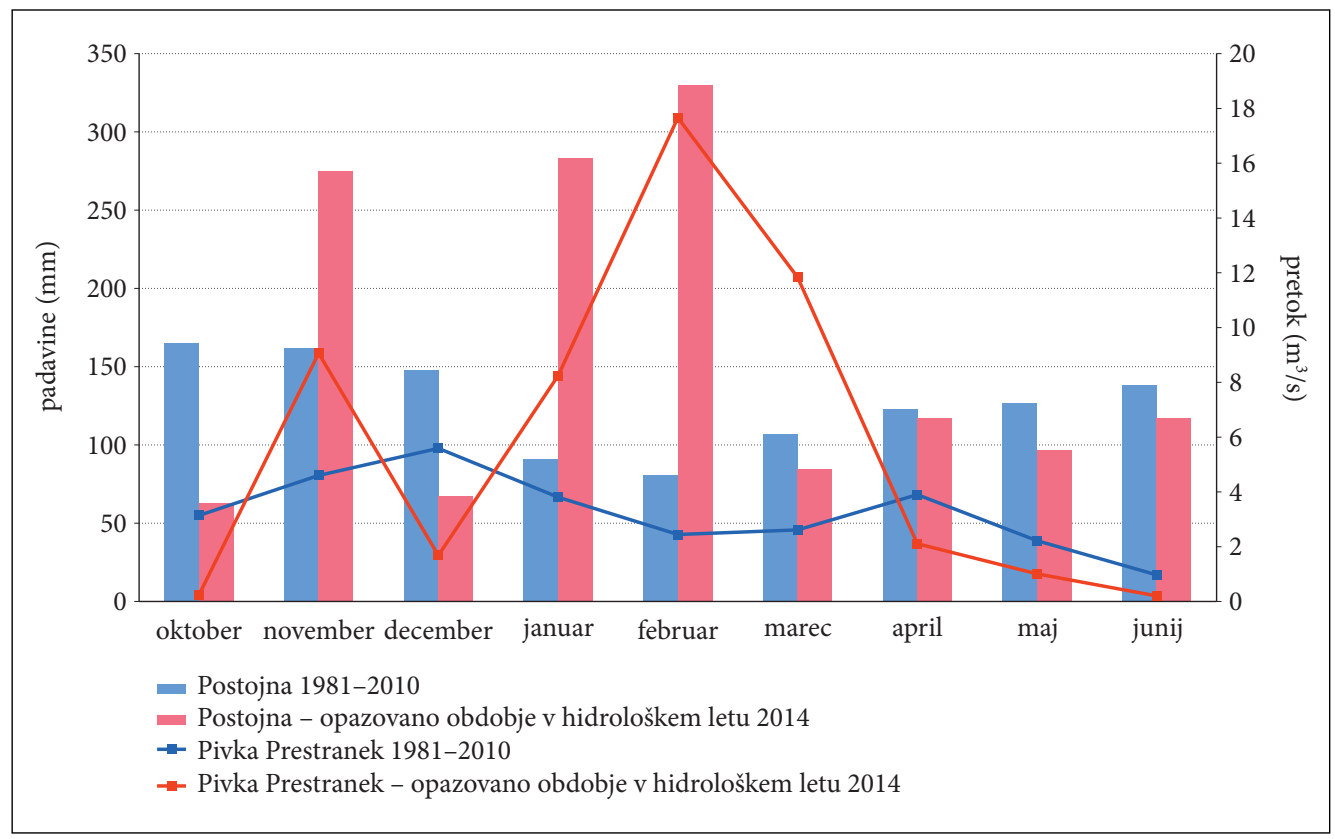

Slika 5: Povprečne mesečne padavine na klimatološki postaji Postojna ter povprečni mesečni pretoki Pivke na vodomerni postaji Prestranek v obdobju 1981-2010 in opazovanem obdobju hidrološkega leta 2014 (Podatki o dnevnih ... 2004a; Podatki o polurnih ... 2014b).

odklon 3,11 m³/s, koeficient variacije pretoka pa 2,63. Omenjeno obdobje je bilo v hidrološkem pogledu povprečno, zato lahko zgornje vrednosti sprejmemo kot dejanske. Na klimatološki postaji Postojna je bilo namreč padavin za $5 \%$ več kot v obdobju 1961-2010, medtem ko lahko iz pretoka Pivke (Prestranek) sklepamo o približno $16 \%$ manjši vodnatosti rek v primerjavi z dolgoletnim obdobjem.

Vodne razmere v preučevanem obdobju hidrološkega leta 2014 pa so bile povsem drugačne (slika 6). V porečju Rakiškega stržena je v primerjavi z obdobjem 1981-2010 padlo za približno $25 \%$ več padavin, največji odstopanji sta bili januarja $(284 \mathrm{~mm})$ in februarja $(330 \mathrm{~mm})$, ko je na klimatološki postaji Postojna padlo za 210 oziroma $310 \%$ več padavin od dolgoletnega povprečja (Podatki o polurnih ... 2014b). Nadpovprečno moker je bil tudi november (170 mm). Povprečni pretok Pivke (Prestranek) je bil v preučevanem obdobju hidrološkega leta 2014 za približno $78 \%$ večji od dolgoletnega povprečja $1981-2010\left(3,25 \mathrm{~m}^{3} / \mathrm{s}\right)$; oktobra $\left(9,06 \mathrm{~m}^{3} / \mathrm{s}\right)$ je bil povprečni pretok presežen za 97 , januarja $\left(8,24 \mathrm{~m}^{3} / \mathrm{s}\right)$ za 116, februarja $\left(17,66 \mathrm{~m}^{3} / \mathrm{s}\right.$ ) za 622 in marca $\left(11,83 \mathrm{~m}^{3} / \mathrm{s}\right.$ ) za $353 \%$ (ARSO 2014b). Najvišji vodostaj Rakiškega stržena je bil izmerjen 2.2.2014 ob 4.00 in je bil $221,79 \mathrm{~cm}$ nad točko odčitka na samodejnem merilniku; povprečen vodostaj je bil $107 \mathrm{~cm}$. V celotnem obdobju meritev je bil merilnik samo $21 \mathrm{ur}$ na suhem.

Povprečni pretok Rakiškega stržena v obdobju 16.10.2013-23.6.2014 je bil 6,51 m³ $/ \mathrm{s}\left(\mathrm{Q}_{\max }=24,40 \mathrm{~m}^{3} / \mathrm{s}\right.$; $\mathrm{Q}_{\min }=0,17 \mathrm{~m}^{3} / \mathrm{s} ; \mathrm{Q}_{95}=17,28 \mathrm{~m}^{3} / \mathrm{s}$ in $\mathrm{Q}_{5}=0,17 \mathrm{~m}^{3} / \mathrm{s}$ ), razmerje med najmanjšim, srednjim in največjim pretokom je bilo $1: 36: 142$. Pretok kaže manjšo spremenljivost kot v obdobju 22.2.1974-31. 12. 1977, koeficient variacije je 0,96. Manjša spremenljivost pretoka je posledica dolgotrajnejših ojezeritev v opazovanem obdobju. Prva ojezeritev je bila v obdobju 5.11.-8.12.2013 (33 dni), druga pa v obdobju 30. 12. 2013-5. 4. 2014 (97 dni). Čeprav je bilo preučevano obdobje hidrološkega leta 2014 zelo mokro, se zdi malo verjetno, da bi lahko bil povprečen pretok Rakiškega stržena tako velik, kot so pokazali izračuni, čeprav Pearsonov koeficient korelacije med izmerjenimi vodostaji potoka in izračunanimi pretoki 


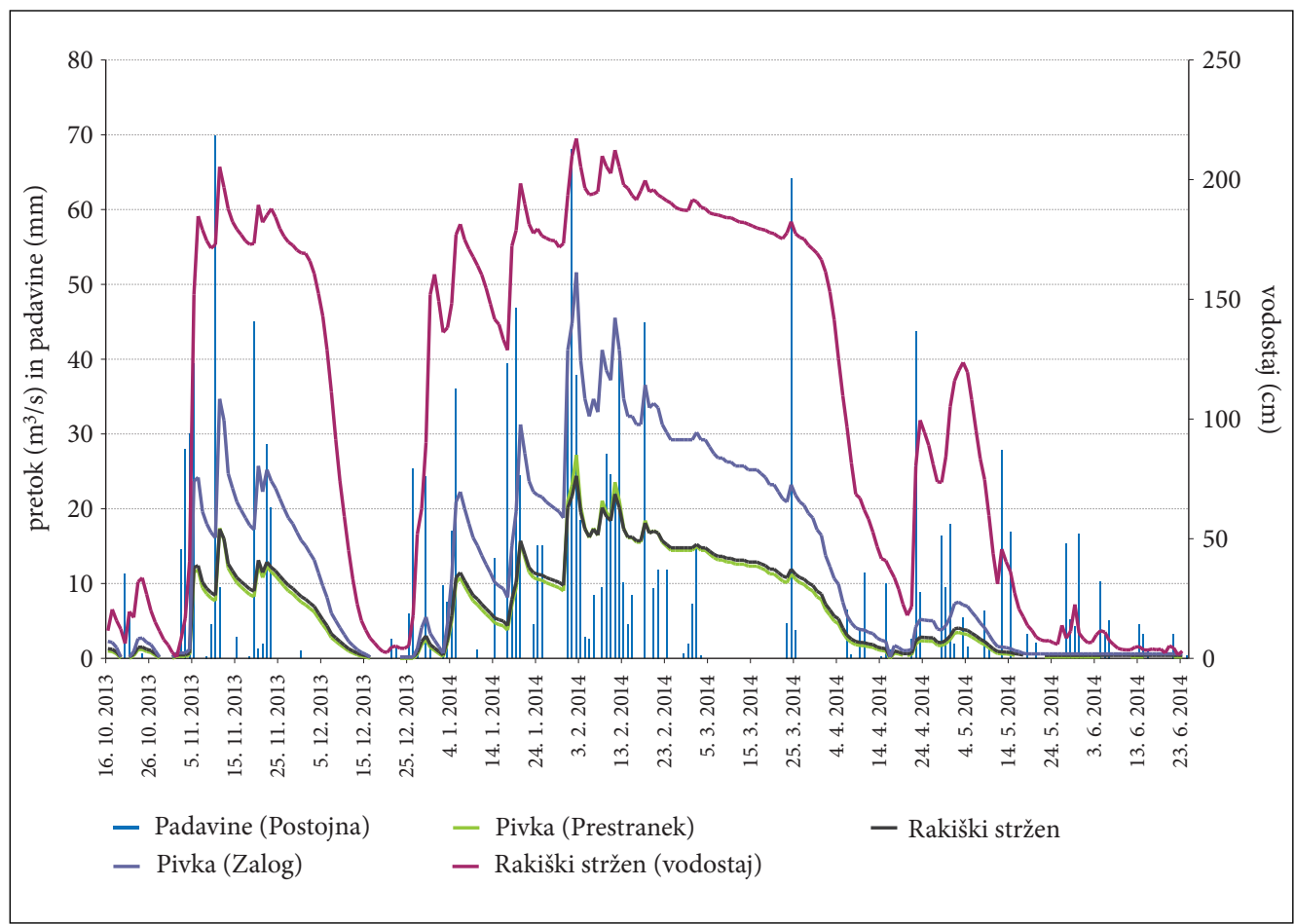

Slika 6: Izmerjeni povprečni dnevni vodostaj Rakiškega stržena, izračunani povprečni dnevni pretok Rakiškega stržena in Pivke na vodomerni postaji Zalog, izmerjeni povprečni dnevni pretok Pivke na vodomerni postaji Prestranek ter dnevne padavine na samodejni meteorološki postaji Postojna v preučevanem obdobju 16. 10. 2013-23. 6. 2014 (Podatki o polurnih ... 2014b).

kaže zelo visoko povezanost $(0,91)$; tudi v času obeh ojezeritev $(0,88$ oziroma 0,93$)$. Ob visokih pretokih namreč Pivka zajezi odtok Rakiškega stržena, voda se razlije v jezero in takrat se njegov pretok zelo zmanjša. Z različnimi simulacijami smo prišli do sklepa, da bi lahko povprečen pretok potoka v opazovanem obdobju bil okrog $2,5 \mathrm{~m}^{3} / \mathrm{s}$.

\section{Kakovostno stanje Rakiškega stržena}

Površinsko porečje Rakiškega stržena je majhno, napajalno zaledje njegovih občasnih kraških izvirov pa so tudi zahodni Javorniki (Kogovšek 1999; Kogovšek s sodelavci 1999) ter Pivka v zgornjem toku (Habič 1989). Z vidika zagotavljanja kakovosti Rakiškega stržena je treba zato računati na potencialne onesnaževalce z dokaj velikega območja. Enkratne meritve, opravljene poleti 1988, so pokazale veliko obremenjenost Rakiškega stržena s kloridi, nitrati, fosfati in sulfati in pa veliko boljšo kakovost vode v vrtinah pri Stari vasi in pri Breznu v Kobiljih grižah, kar po mnenju Habiča (1989) kaže, da onesnažene ponikalnice v zgornjem porečju Pivke ne vplivajo bistveno na kakovost vode v vrtinah.

Glavni onesnaževalec Rakiškega stržena je nedvomno CČN, saj se njene prečiščene odpadne vode iztekajo neposredno v potok (slika 7). Na mehansko-biološko čistilno napravo, projektirano za 15.000 populacijskih enot, sta priključeni Postojna in Stara vas, od večjih onesnaževalcev po predčiščenju klavniške (Postojnske mesnine d. o. o.) in galvanske odpadne vode (Fluidmaster d. o. o.; nekdanji LIV), odpadne 


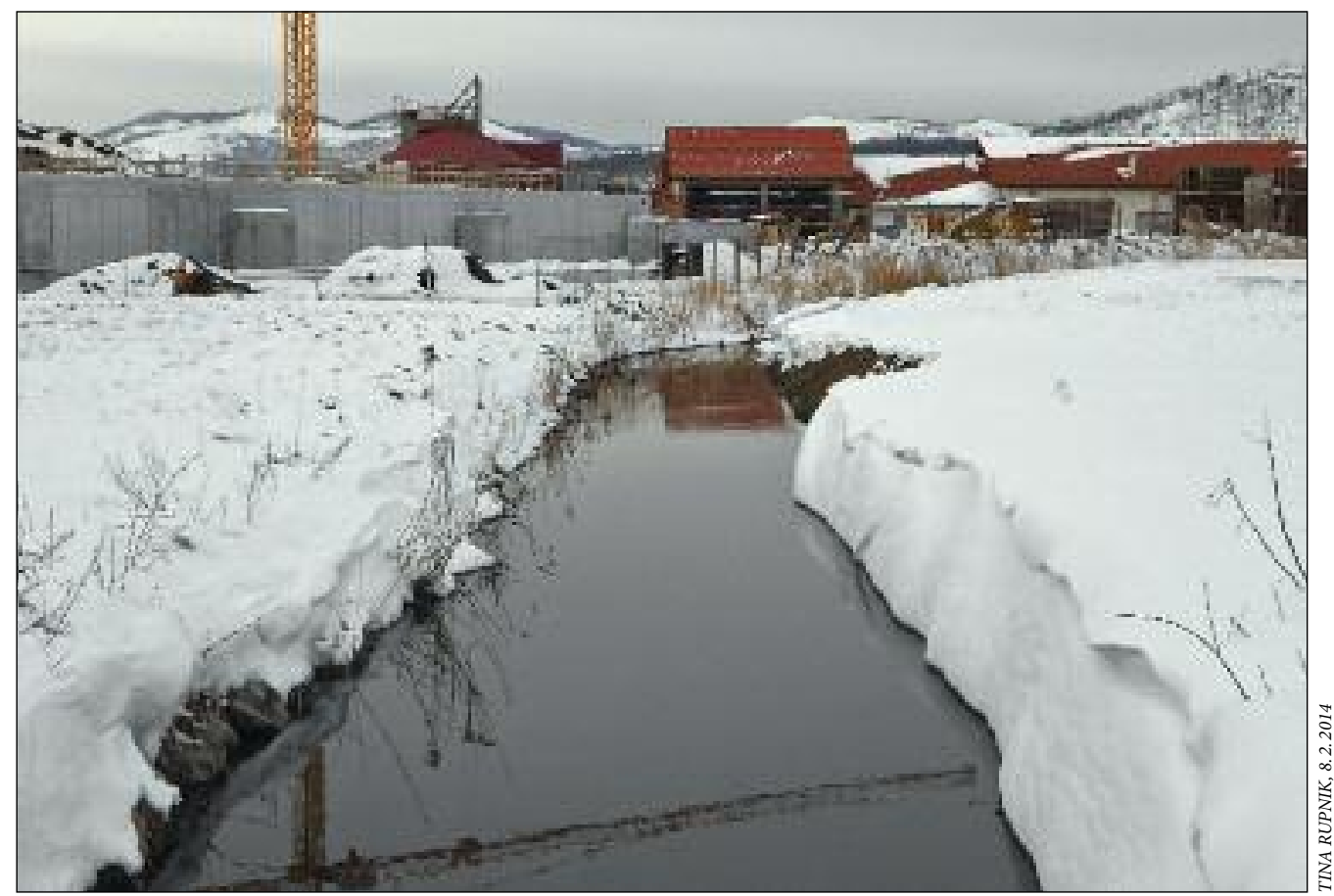

Slika 7: Iztok iz CČN Postojna, v ozadju izgradnja nove.

vode Zdravstvenega doma Postojna ter deponijske odpadne vode iz odlagališča nenevarnih odpadkov Stara vas. Industrijske odpadne vode predstavljajo približno $1 \%$ vse očiščene vode (Poročilo o obratovalnem monitoringu ... 2015; Centralna čistilna naprava Postojna 2014). Pred izgradnjo čistilne naprave so odpadne vode iz Postojne neprečiščene odtekale v Rakiški stržen. V času poletnih nizkih voda predstavlja iztok iz čistilne naprave praktično edino vodo Rakiškega stržena. Težave s prekomernim obremenjevanjem Rakiškega stržena iz čistilne naprave se pojavijo tudi ob dolgotrajnejših padavinah, ko del vode brez predhodnega biološkega čiščenja odteka v potok.

Odlagališče Stara vas deluje od leta 1968, letno pa se na njem odloži približno 8500 t nenevarnih odpadkov (Petrič in Šebela 2005). Odlagališče ima urejen sistem zbiranja izcednih vod, površinske vode, ki niso v stiku z odpadki, pa so speljane v ponikalnico (Petrič in Šebela 2005). Občasne meritve kakovosti vode v $450 \mathrm{~m}$ oddaljenem izviru iz jame Fužina so pokazale povečane vrednosti organskih halogenov, amonija, nitratov in sulfatov, ki skoraj gotovo izvirajo iz odlagališča (Kogovšek 1996; Petrič in Šebela 2005). Potencialni onesnaževalec občasnih kraških izvirov Rakiškega stržena so tudi vojaške aktivnosti na Osrednjem vadišču Slovenske vojske Postojna na Počku (težke kovine, eksplozivna sredstva, nafta, olja ...) ter neurejeno odvajanje in čiščenje odpadnih vod v zgornjem toku Pivke. Med onesnaževalci so tudi neprečiščene odpadne vode iz Rakitnika, ki odtekajo v potok, ter kmetijstvo (spiranje gnojevke s travnikov) in promet. V neposrednem zaledju občasnih kraških izvirov je železniška proga; prek Rakiškega stržena je speljana glavna prometnica Postojna-Ilirska Bistrica.

\subsection{Temperatura, $\mathrm{pH}$, trdota in vsebnost raztopljenega kisika}

Povprečna temperatura vode, izmerjena s samodejnim merilnikom, nameščenim pod mostom v Rakitniku, je bila v preučevanem obdobju 10,1 , najnižja $-0,7$, najvišja pa $28,6^{\circ} \mathrm{C}$. Skladno s pričakovanji 
je temperatura najmanj nihala na izviru Fužina, zgolj za $2,6^{\circ} \mathrm{C}$. Vrednosti $\mathrm{pH}$, ki so se na merilnih mestih gibale med 7 in 8,5 , pričakovano kažejo na bazičnost vod; razlike med merilnimi mesti so zanemarljive. Karbonatna trdota je bila na merilnih mestih med 7 in $14^{\circ} \mathrm{N}$, celokupna pa med 7 in $17^{\circ} \mathrm{N}$; med posameznimi merilnimi mesti ni bilo večjih razlik. V času ojezeritve sta bili zaradi krajšega zadrževanja vode v podzemlju in prsteh obe trdoti nižji za približno $2^{\circ} \mathrm{N}$.

Vsebnost raztopljenega kisika v vodi je pomemben pokazatelj onesnaženosti vodnega okolja, ki je odvisna od več dejavnikov, najbolj od aktivnosti vodnih organizmov in temperature. Na izpustih odpadnih voda, bogatih $\mathrm{z}$ organskimi snovmi, je zaradi povečane mikrobne dejavnosti vsebnost kisika v primerjavi z neobremenjenimi sistemi manjša (Urbanič in Toman 2003). Izmerjene koncentracije raztopljenega kisika na Rakiškem strženu so nizke in kažejo na precejšnjo obremenjenost $\mathrm{z}$ organskimi snovmi. Pričakovano so bile najvišje povprečne koncentracije raztopljenega kisika izmerjene na izviru Fužina $(9,4 \mathrm{mg} / \mathrm{l})$, medtem ko smo na drugih dveh merilnih mestih izmerili povprečno vrednost 7,4 mg/l. V raziskavi desnih pritokov Reke v njenem povirju je bila povprečna koncentracija kisika mnogo višja, nad 10 mg/l; najnižje koncentracije so bile zabeležene poleti, na merilnih mestih pod naselji z neurejenim odvajanjem odpadnih voda (2,4 mg/l) (Počkar, Kovačič in Peric 2014). Izmerjene povprečne koncentracije kisika v Rakiškem strženu so bile v času ojezeritve visoke $(10,4 \mathrm{mg} / \mathrm{l})$, medtem ko so bile v času nizkih voda veliko nižje $(6 \mathrm{mg} / \mathrm{l})$. Ob nizkih vodah so bile razlike med merilnimi mesti največje; na izviru Fužina je bila povprečna koncentracija 8,4 (77\% nasičenost), na sotočju 4,6 (45\% nasičenost) in v Rakitniku $5 \mathrm{mg} \mathrm{O} / 1$ (51 \% nasičenost). Slednji vrednosti sta že pod mejo $5 \mathrm{mg} \mathrm{O}_{2} / 1$, ki jo Urbanič in Toman (2003) navajata kot minimum za preživetje številnih vrst odraslih organizmov v vodi. Najnižje koncentracije kisika, nižje od kritične meje $2 \mathrm{mg} / \mathrm{l}$, ki že povzročajo pogine rib in drugih organizmov (Urbanič in Toman 2003), so bile izmerjene v Rakitniku $(1,5 \mathrm{mg} / \mathrm{l} ; 24.12$.) in na sotočju $(1,8 \mathrm{mg} / \mathrm{l} ; 18.10 ., 26.5$. in 18. 6.), kar dokazuje na obremenjevanje potoka z izpustom iz CČN in z neprečiščenimi odpadnimi vodami iz Rakitnika.

\subsection{Nitrati, nitriti, amonijevi ioni in fosfati}

Količina nitratov $\mathrm{v}$ neonesnaženih vodah sezonsko niha v povezavi $\mathrm{z}$ aktivnostjo primarnih proizvajalcev in odmiranjem organizmov, vendar običajno ne presega $1 \mathrm{mg} / \mathrm{l}$ (Urbanič in Toman 2003). Višje koncentracije, do $10 \mathrm{mg} / \mathrm{l}$, so povezane s spiranjem z gnojenih kmetijskih zemljišč, koncentracije nad $25 \mathrm{mg} / \mathrm{l}$ pa kažejo na onesnaženje s komunalnimi ali industrijskimi odplakami (Urbanič in Toman 2003; Vovk Korže in Bricelj 2004). Dovoljena koncentracija $\mathrm{NO}_{3}{ }^{-} \mathrm{v}$ pitni vodi je $50 \mathrm{mg} / \mathrm{l}$ (Pravilnik o pitni vodi 2004-2009). Ta vrednost je bila na Rakiškem strženu v preučevanem obdobju presežena zgolj enkrat, na merilnem mestu na sotočju $(70 \mathrm{mg} / \mathrm{l} ; 18.6$. $)$. Mejni vrednosti za koncentracije nitratov površinskih vodotokov, ki sodijo v 1. skupino nitratnih tipov rek (sem sodi tudi Pivka s pritoki) (Vrednotenje ekološkega stanja ... 2009), sta 3,2 (zelo dobro ekološko stanje) oziroma 6,5 mg/l (dobro ekološko stanje). Povprečna koncentracija nitratov v Rakiškem strženu v opazovanem obdobju ( $9,3 \mathrm{mg} / \mathrm{l})$, ki je bila skoraj še enkrat višja od izmerjene na pritokih Reke v njenem povirju (Počkar, Kovačič in Peric 2014), je bistveno presegla obe mejni vrednosti, kar kaže na slabo ekološko stanje potoka z vidika vsebnosti nitratov. Ob nizkih vodah je bila povprečna koncentracija $\mathrm{NO}_{3}{ }^{-}$na vseh merilnih mestih $12,7, \mathrm{v}$ času ojezeritve pa je bila zaradi učinka redčenja za pol manjša $(6,3 \mathrm{mg} / \mathrm{l})$. Najmanj se je koncentracija nitrata spreminjala na izviru Fužina, kjer smo tudi sicer zabeležili najnižje povprečne koncentracije (4 mg/l), ki pa kljub temu presegajo mejno vrednost za zelo dobro ekološko stanje. Najvišjo povprečno koncentracijo nitrata smo izmerili na merilnem mestu na sotočju; ob nizkih vodah je bila 21,9 , ob ojezeritvi pa 6,6 mg/l, kar kaže na onesnaženje s komunalnimi odplakami iz CČN. Te vrednosti so primerljive z izmerjenimi na Rakiškem strženu v Rakitniku; ob ojezeritvi 6,9 in ob nizkih vodah $11 \mathrm{mg} / \mathrm{l}$. Koncentracije nitrata v Rakiškem strženu kažejo na pomemben vpliv obremenjevanja iz kmetijstva ter s komunalnimi odplakami.

Nitrit se v vodi pojavlja zaradi podobnih vzrokov kot nitrat, njegova mejna koncentracija za pitno vodo je $0,50 \mathrm{mg} / \mathrm{l}$ oziroma $0,10 \mathrm{mg} / \mathrm{l}$ po pripravi za distribucijo (Pravilnik o pitni vodi 2004-2009). Prva 


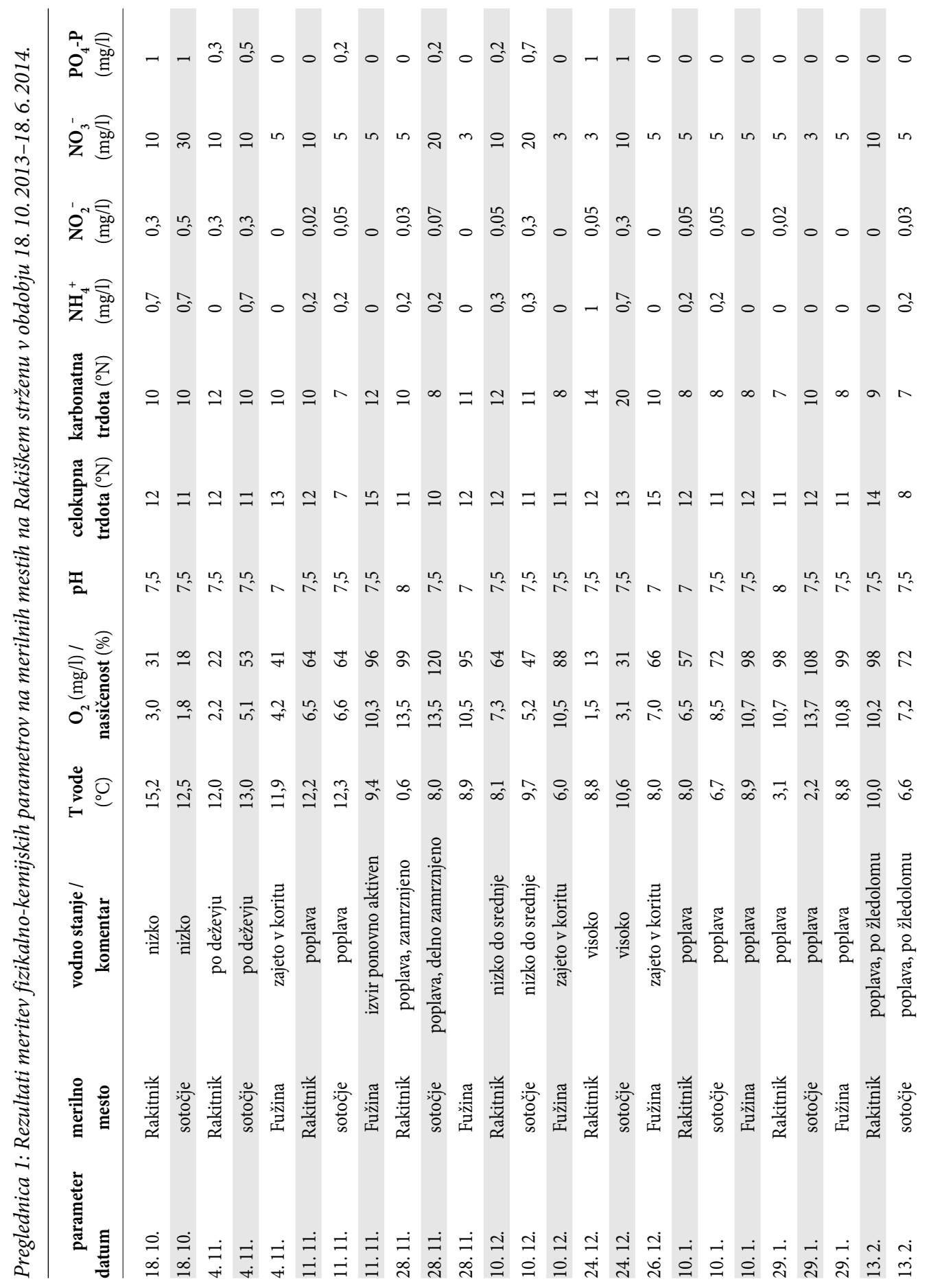




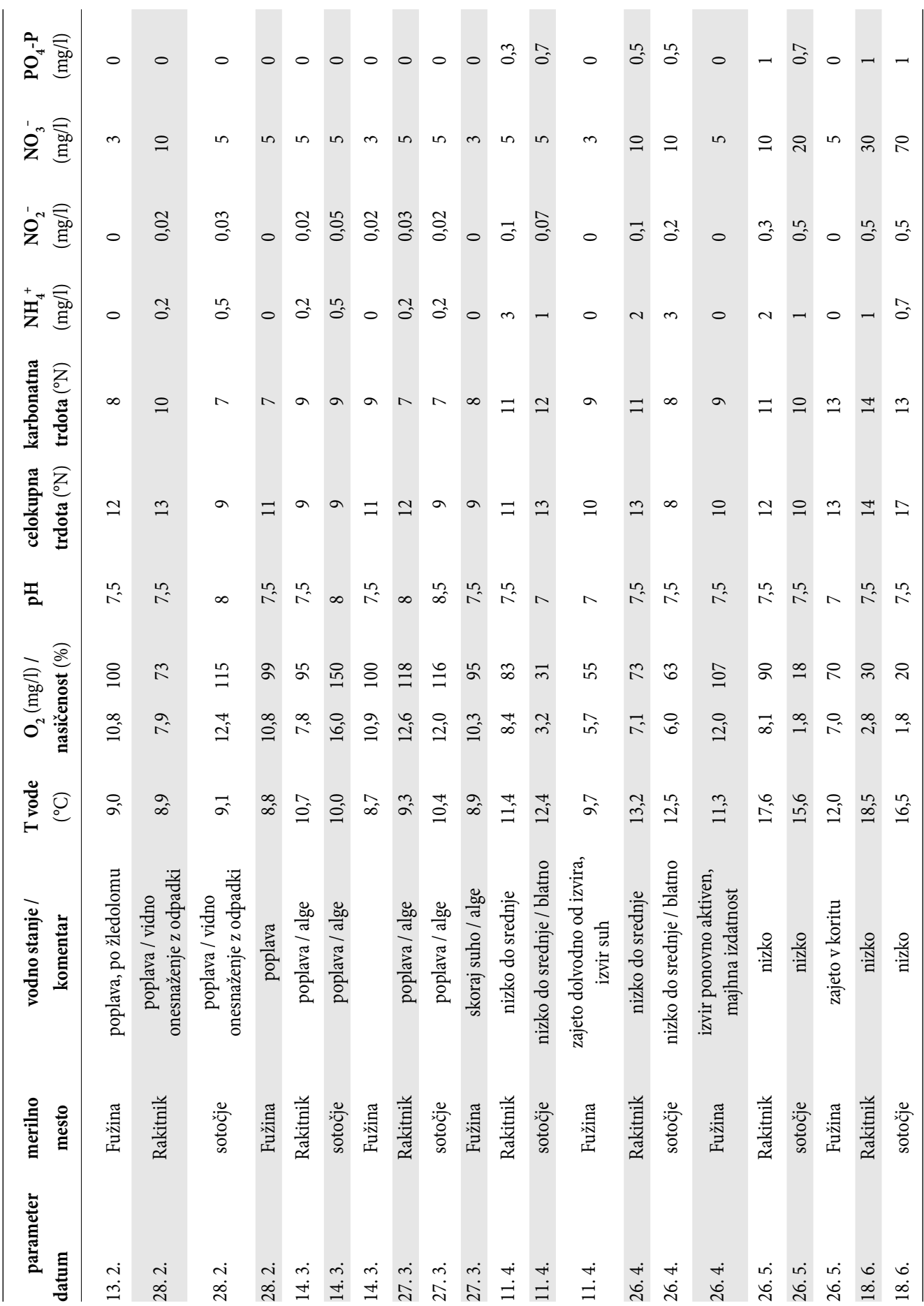


koncentracija na Rakiškem strženu ni bila nikoli presežena. Na izviru Fužina smo samo enkrat izmerili vsebnost nitrita $(0,02 \mathrm{mg} / \mathrm{l})$, koncentracija je bila enaka kot ob meritvi, opravljeni v okviru monitoringa izcednih voda $\mathrm{z}$ odlagališča Stara vas (Poročilo o monitoringu podzemnih voda ... 2014) v zajetju v Stari vasi. Najvišja povprečna koncentracija nitrita je bila izmerjena na sotočju (ob ojezeritvi 0,04 in ob nizkih vodah $0,3 \mathrm{mg} / \mathrm{l}$ ), nekoliko nižji sta bili njegovi povprečni koncentraciji v Rakitniku (ob ojezeritvi 0,02 in ob nizkih vodah $0,2 \mathrm{mg} / \mathrm{l}$ ).

Amonij v vodi je posledica komunalnega, kmetijskega in industrijskega onesnaženja, običajne koncentracije ne presegajo 0,2 mg/l. Prag zaznavanja vonja v vodi za amonij je približno 1,5, prag zaznavanja okusa pa $35 \mathrm{mg} / \mathrm{l}$. Amonij je lahko pokazatelj svežega organskega oziroma fekalnega onesnaženja (Nacionalni inštitut ... 2014). Mejna vrednost za pitno vodo je 0,50 mg/l (Pravilnik o pitni vodi 2004-2009). Čeprav smo pričakovali, da bo zaradi iztoka iz CČN najvišja povprečna koncentracija amonija izmerjena na sotočju (ob ojezeritvi 0,25 in ob nizkih vodah $1,01 \mathrm{mg} / \mathrm{l}$ ), pa je bila le-ta izmerjena v Rakitniku (ob ojezeritvi 0,15 in ob nizkih vodah $1,25 \mathrm{mg} / \mathrm{l}$ ), kar lahko kaže na onesnaženje $\mathrm{z}$ neprečiščenimi odpadnimi vodami iz naselja, speljanimi neposredno v potok. Na izviru Fužina amonija nismo izmerili, je bil pa s koncentracijo 0,4 mg/l izmerjen na zajetju v Stari vasi 6.11.2013 (Poročilo o monitoringu podzemnih voda ... 2014). Meritve na Rakiškem strženu so pokazale, da je potok zelo obremenjen $\mathrm{z}$ amonijem, največji delež k obremenjevanju pa prispeva CČN. Podatki monitoringa izcednih voda na iztoku iz čistilne naprave v obdobju hidrološkega leta 2014 kažejo povprečno koncentracijo $11,8 \mathrm{mg} \mathrm{NH}_{4}^{+} / 1$ (Poročilo o obratovalnem monitoringu ... 2015). Po dolgotrajnejšem deževju, ko se določen del mehansko očiščene vode iz čistilne naprave preliva $\mathrm{v}$ potok brez predhodnega biološkega čiščenja, so lahko izmerjene še mnogo višje koncentracije; 20.3. 2014 so tako izmerili kar $35 \mathrm{mg} \mathrm{NH}_{4}^{+} / 1$ (Poročilo o obratovalnem monitoringu ... 2015).

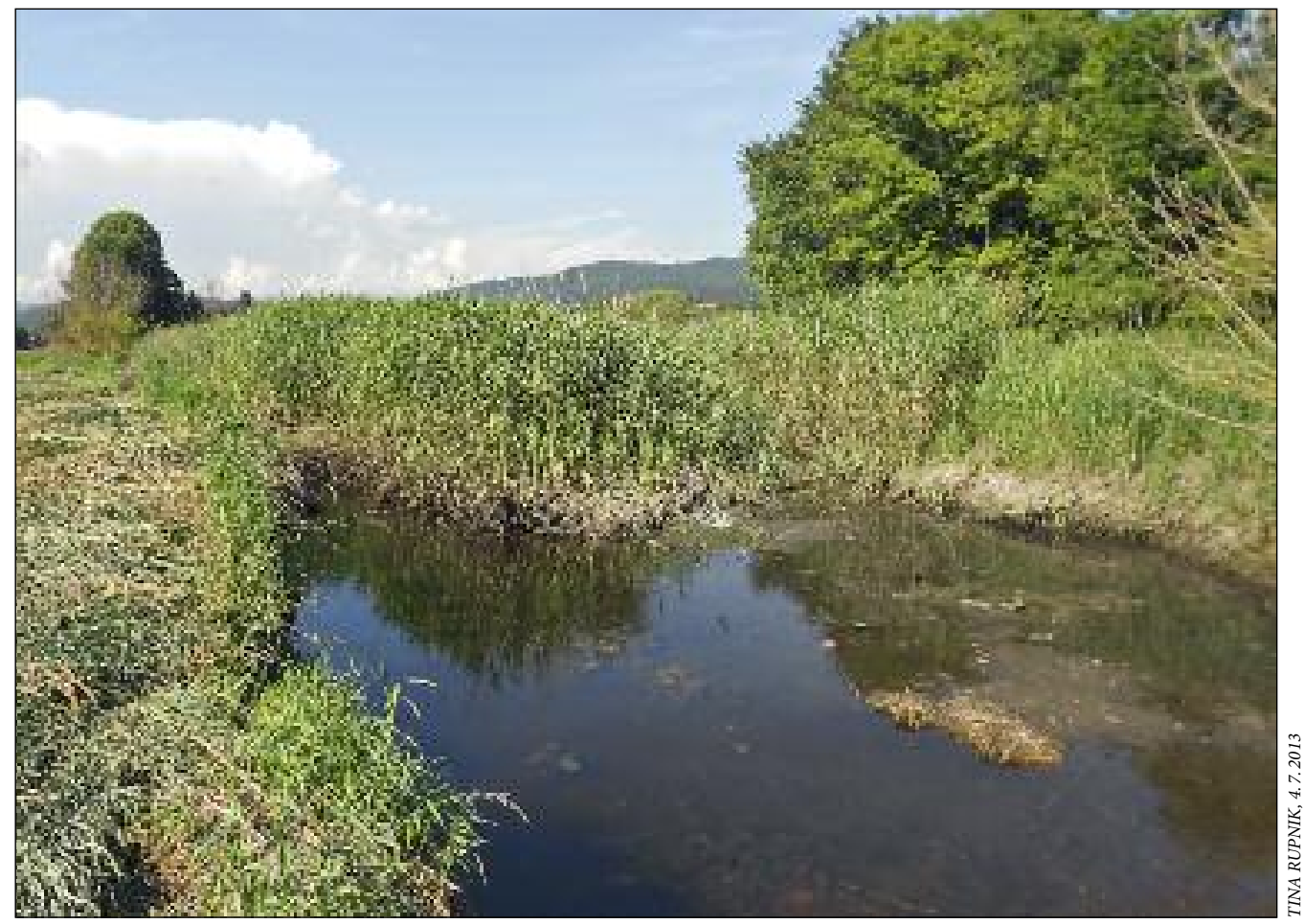

Slika 8: Sotočje severnega in vzhodnega kraka Rakiškega stržena. 
Naravni viri fosforja $\mathrm{v}$ vodi so preperele kamnine in razgrajene organske snovi; njegova koncentracija v neonesnaženih vodah običajno ne presega $0,1 \mathrm{mg} / \mathrm{l}$ (Urbanič in Toman 2003). Fosfati se v vodi pojavijo zaradi uporabe umetnih gnojil (do $0,25 \mathrm{mg} / \mathrm{l}$ ), višje koncentracije pa povzročajo izpusti komunalnih in industrijskih odplak (Urbanič in Toman 2003). Na izviru Fužina fosfatov nismo izmerili. Večina fosfatov prihaja v Rakiški stržen s prečiščeno vodo iz CČN, kar dokazujeta njegova najvišja izmerjena povprečna koncentracija na sotočju (ob ojezeritvi 0,05 in ob nizkih vodah $0,8 \mathrm{mg} / \mathrm{l}$ ) in povprečna koncentracija celotnega fosforja na iztoku iz čistilne naprave v preučevanem obdobju, ki je bila 2,6 mg/l; najvišja koncentracija je bila malo nižja od $4 \mathrm{mg} / \mathrm{l}$ (Poročilo o obratovalnem monitoringu ... 2015). Ob nizkih vodah, ko voda iz čistilne naprave predstavlja edino vodo Rakiškega stržena, je bila povprečna koncentracija fosfatov $(0,7 \mathrm{mg} / \mathrm{l}) \mathrm{v}$ Rakitniku približno enako visoka kot na sotočju, medtem ko v času ojezeritve zaradi učinka redčenja fosfati v Rakitniku niso bili izmerjeni.

\section{Sklep}

S pomočjo hidroloških podatkov smo ocenili srednji pretok Rakiškega stržena za daljše obdobje $\left(1,18 \mathrm{~m}^{3} / \mathrm{s}\right)$; v zelo vodnatem hidrološkem letu 2014 smo ga ocenili na $2,5 \mathrm{~m}^{3} / \mathrm{s}$. Podatki kažejo na veliko spremenljivost pretoka, kar je treba upoštevati pri zagotavljanju ustreznega kakovostnega stanja potoka. Prihodnji izziv ostaja določitev ustrezne pretočne krivulje potoka, do katere bi prišli z neprekinjenim merjenjem vodostaja Rakiškega stržena na merilnem mestu pod mostom v Rakitniku in večkratnim merjenjem pretoka ob različnih vodnih stanjih. Na podlagi pretočne krivulje bi lahko bolj natančno opredelili vrednosti njegovih karakterističnih pretokov, zlasti najmanjših, saj je takrat učinek redčenja neznaten, koncentracije onesnaževal v vodi pa posledično najvišje.

Rakiški stržen si kraško zaledje deli z najpomembnejšim virom pitne vode na območju, kraškim izvirom Malenščica na Planinskem polju, hkrati pa njegovo porečje leži tudi v hidrografskem zaledju izvira Vipava, ki je prav tako zajet za vodooskrbo. Že rezultati predhodnih raziskav (Habič 1989; Kogovšek 1999; Kogovšek s sodelavci 1999) so pokazali, da je treba pri varovanju kakovosti Rakiškega stržena zagotavljati ustrezne ukrepe tudi v zgornjem porečju Pivke in na zahodnih Javornikih, kjer je več potencialnih onesnaževalcev (neprečiščene odpadne vode iz naselij, vojaško vadišče, odlagališče nenevarnih odpadkov, promet in drugi). Meritve, opravljene v obdobju hidrološkega leta 2014, večjega obremenjevanja iz naštetih virov na izviru Fužina sicer niso pokazale. Vplivi odlagališča so bili dokazani ob nekaterih predhodnih raziskavah (Kogovšek 1996; Petrič in Šebela 2005). Očitno je ukrep odvajanja izcednih vod z odlagališča odpadkov Stara vas na CČN pripomogel k boljši kakovosti izvira Fužina in drugih občasnih kraških izvirov v njegovi bližini.

Kakovostno stanje izvira se bo gotovo izboljšalo z zagonom vseh zgrajenih komunalnih čistilnih naprav v zgornjem porečju Pivke (Knežak, Bač, Zagorje, Pivka), pri čemer pa se ne smejo ponoviti že videni primeri, ko iztoki nezadostno prečiščenih voda iz čistilnih naprav v ponore ali jame povzročajo dodatno, koncentrirano onesnaževanje kraške podtalnice - primer Centralne čistilne naprave Sežana (terciarno čiščenje) in Čistilne naprave Nova vas (sekundarno čiščenje) (Kogovšek, Prelovšek in Petrič 2008; Mezinec 2012).

Za zagotavljanje kakovosti virov pitne vode na območju, s tem pa tudi Rakiškega stržena, je potrebno celovito varovanje kraške podtalnice na območju Javornikov in Zgornje Pivke, kar pa s predpisi še ni ustrezno urejeno. Zaradi navzkrižja interesov med vojaško dejavnostjo (vojaško vadišče Poček) in varovanjem pitne vode do sedaj še ni bil sprejet, sicer že leta 2009 pripravljen, Odlok o varovanju vodnih virov območja Javornikov (Culver s sodelavci 2012), pa čeprav je zavarovanje zgolj prvi korak pri vzpostavljanju celovitega trajnostnega upravljanja $z$ viri pitne vode. Predpisom morajo namreč slediti učinkoviti ukrepi in nadzor nad njihovim izvajanjem, ki pa je pogosto zelo pomanjkljiv.

Rezultati so pokazali, da je z vidika kakovosti vode, veliko bolj kot občasni kraški izviri, problematičen površinski del porečja Rakiškega stržena, kamor se iztekajo prečiščene odpadne vode iz CČN. 
Kakovost potoka je slabša tudi dolvodno od Rakitnika, saj je kanalizacijsko omrežje v naselju trenutno šele v izgradnji. Kljub temu, z izjemo amonija, najvišje dovoljene koncentracije za pitno vodo (Pravilnik o pitni vodi 2004-2009) pri ostalih parametrih na obeh merilnih mestih niso bile presežene. Primerjava s podatki na iztoku iz čistilne naprave (Poročilo o obratovalnem monitoringu ... 2015) je pokazala, da so koncentracije fosfatov in amonija na iztoku v povprečju nekajkrat višje, kar lahko pomeni, da se do sotočja voda deloma že prečisti, delno pa lahko razlike pripišemo različnim postopkom opravljanja analiz.

Sklenemo lahko, da CČN zaradi preobremenjenosti čezmerno obremenjuje Rakiški stržen, saj je učinek čiščenja pri številnih parametrih premajhen, koncentracije določenih spojin pa so v iztoku večkrat presežene. S posodobitvijo čistilne naprave se bo njena zmogljivost povečala na $21.000 \mathrm{PE}$, nova naprava pa bo poleg običajnega mehanskega in biološkega čiščenja imela še tretjo in četrto stopnjo čiščenja odpadnih voda, ki zajemata še odstranjevanje fosforja, nitratov ter uničenje škodljivih mikroorganizmov (Centralna čistilna naprava Postojna 2014).

Z zagonom nove čistilne naprave, predvidoma koncem leta 2015, na katero bodo priključena tudi gospodinjstva iz Rakitnika, se bo kakovost Rakiškega stržena, s tem pa tudi Pivke, pričakovano izboljšala. Hkrati pa velja razmisliti tudi o vzporednih sonaravnih ukrepih za izboljšanje kakovostnega stanja Rakiškega stržena. Uravnani in zamočvirjen svet ob potoku, poraščen z vlagoljubnim rastjem, ki kmetijsko že sedaj ni izrabljen, bi lahko izkoristili kot naravni čistilni sistem za zniževanje koncentraciji različnih onesnaževal iztočne vode iz čistilne naprave. Namesto ukrepov izsuševanja, ki so bili značilni za pretekla obdobja, bi lahko delež zamočvirjenih zemljišč celo povečali.

Zahvala: Avtorja se zahvaljujeva Inštitutu za raziskovanje krasa ZRCSAZU za izposojo avtomatskega merilnika za opravljanje meritev na Rakiškem strženu, še posebej Franju Droletu, ki je pomagal pri njegovi namestitvi. Zahvaljujeva se tudi podjetju Kovod Postojna d.o.o., upravljavcu CČN, ter podjetju Publicus d.o.o., upravljavcu odlagališča nenevarnih odpadkov Stara vas, za vse posredovane podatke.

\section{Viri in literatura}

Buser, S., Grad, K, Pleničar, M. 1967: Osnovna geološka karta SFRJ 1: 100.000, list Postojna. Zvezni geološki zavod. Beograd.

Centralna čistilna naprava Postojna, 2014. Medmrežje: http://www.kovodpostojna.si/dejavnosti/ cistilne-naprave/ccn-postojna (30.12.2014).

Culver, D., Debevc, B., Knez, M., Kovačič, G., Kranjc, A., Mulec, J., Pipan, T., Prelovšek, M., Ravbar, N., Semeja, A., Slabe, T., Šebela, S., Zupan Hajna, N. 2012: Krasoslovje v razvojnih izzivih na krasu. 2, Gradnja, turizem, ekologija, varovanje. Ljubljana.

Ferko, L. 2014: Na Pivškem so dobili novo jezero. Primorske novice 68-104. Koper.

Gospodarič, R. 1989: Prispevek k vodnogospodarskim osnovam Pivke. Acta carsologica 18. Ljubljana.

Gospodarič, R., Habe, F., Habič, P. 1968: Vodni viri za oskrbo Postojne. Inštitut za raziskovanje krasa ZRCSAZU. Postojna.

Habič, P. 1985: Vodna gladina v Notranjskem in Primorskem krasu Slovenije. Acta carsologica 13. Ljubljana. Habič, P. 1989: Kraška bifurkacija na jadransko črnomorskem razvodju. Acta carsologica 18. Ljubljana. Kogovšek, J. 1996: Kako smetišča ogrožajo kakovost kraške vode. Annales 6-9. Koper.

Kogovšek, J. 1999: Nova spoznanja o podzemnem pretakanju vode v severnem delu Javornikov (visoki kras). Acta carsologica 28-1. Ljubljana.

Kogovšek, J., Knez, M., Mihevc, A., Petrič, M., Slabe, T., Šebela, S. 1999: Military training area in Kras (Slovenia). Environmental Geology 38-1. Berlin. DOI: http://dx.doi.org/10.1007/s002540050402

Kogovšek, J., Petrič, M. 2004: Advantages of longer-term tracing - three case studies from Slovenia. Environmental Geology 47-1. Berlin. DOI: http://dx.doi.org/10.1007/s00254-004-1135-8 
Kogovšek, J., Prelovšek, M., Petrič, M. 2008: Underground water flow between Bloke plateau and Cerknica polje and Hydrologic function of Križna jama, Slovenia. Acta carsologica 37, 2-3. Ljubljana.

Kranjc, A. 1985: Poplavni svet na Pivki. Ljudje in kraji ob Pivki. Postojna.

Mezinec, P. 2012: Voda iz čistilne naprave ne sme v jamo Bukovnik. Primorske novice (27.12.2012). Medmrežje: http://www.primorske.si/Primorska/Srednja-Primorska/Voda-iz-cistilne-naprave-ne-sme-v-jamo-Bukovnik.aspx (25.3.2015).

Nacionalni inštitut za javno zdravje. O posameznih parametrih Pravilnika o pitni vodi na kratko. Ljubljana, 2014. Medmrežje: http://www.ivz.si/Mp.aspx?ni=115\&_5_id=409\&_5_action=ShowNewsFull (30.12.2014).

Petrič, M., Kogovšek, J. 2005: Hidrogeološke značilnosti območja presihajočih Pivških jezer. Acta carsologica 34-3. Ljubljana.

Petrič, M., Šebela, S. 2005: Hydrogeological research as a basis for the preparation of the plan of monitoring groundwater contamination: A case study of the Stara vas landfill near Postojna (SW Slovenia). Acta carsologica 34-2. Ljubljana.

Pleničar, M. 1970: Osnovna geološka karta SFRJ 1:100.000, tolmač lista Ilirska Bistrica in Postojna. Zvezni geološki zavod. Beograd.

Počkar, T., Kovačič, G., Peric, B. 2014: Hidrogeografske značilnosti in kakovostno stanje vodotokov v povirju Reke. Geografski vestnik 86-1. Ljubljana. DOI: http://dx.doi.org/10.3986/GV86101

Podatki o dnevnih vodostajih in pretokih na vodomernih postajah Prestranek in Zalog na Pivki v obdobju 22. 2. 1974-31. 12. 1977, dnevnih pretokih Pivke na vodomerni postaji Prestranek v obdobju 1. 10.2013-30.6.2014 in povprečnih mesečnih pretokih Pivke na vodomerni postaji Prestranek v obdobju 1961-2010. Agencija Republike Slovenije za okolje. Ljubljana, 2014.

Podatki o polurnih padavinah na samodejni meteorološki postaji Postojna v obdobju 1.10.2013-30.6.2014 in povprečnih mesečnih padavinah v obdobju 1961-2010 na klimatološki postaji Postojna. Agencija Republike Slovenije za okolje. Ljubljana, 2014.

Poročilo o monitoringu podzemnih voda za odlagališče nenevarnih odpadkov Stara vas - Postojna za leto 2013. ERICo Velenje, Inštitut za ekološke raziskave d. o. o. Velenje, 2014.

Poročilo o obratovalnem monitoringu za komunalno čistilno napravo CČN Postojna za leto 2013. Nacionalni laboratorij za zdravje, okolje in hrano, Center za okolje in hrano, Oddelek za okolje in zdravje Nova Gorica. Nova Gorica, 2014.

Poročilo o obratovalnem monitoringu za komunalno čistilno napravo CČN Postojna za leto 2014. Nacionalni laboratorij za zdravje, okolje in hrano, Center za okolje in hrano, Oddelek za okolje in zdravje Nova Gorica. Nova Gorica, 2015.

Pravilnik o pitni vodi. Uradni list Republike Slovenije 19/2004, 35/2004, 26/2006, 92/2006, 25/2009. Ljubljana.

Rajšp, V., Ficko, M. (ur.) 1997: Slovenija na vojaškem zemljevidu 1763-1787, 3. zvezek. Ljubljana.

Raster realne evapotranspiracije v Sloveniji $100 \times 100$ m, 1971-2000. Agencija Republike Slovenije za okolje. Ljubljana, 2008.

Rižnar, I. 1997: Geologija okolice Postojne. Magistrsko delo, Naravoslovnotehniška fakulteta Univerze v Ljubljani. Ljubljana.

Šabec, D. 2014. O regulacijah na Rakiškem strženu. Ustni vir, domačin iz Rakitnika, rojen leta 1930.

Temeljni topografski načrt 1:5000, list Postojna 3. Geodetska uprava Socialistične Republike Slovenije. Ljubljana, 1978.

Urbanič, G., Toman, M. J. 2003: Varstvo celinskih voda. Ljubljana.

Uredba o stanju površinskih voda. Uradni list Republike Slovenije 14/2009. Ljubljana

Vovk Korže, A., Bricelj, M. 2004: Vodni svet Slovenije. Priročnik za interdisciplinarno proučevanje voda. Ljubljana.

Vrednotenje ekološkega stanja površinskih voda s splošnimi fizikalno-kemijskimi elementi. Ministrstvo za okolje in prostor. Ljubljana, 2009. 


\section{Summary: The Rakiški Stržen brook: hydrogeographic characteristics and water quality assessment}

(translated by Primož Kovačič)

The Rakiški Stržen brook is the last right-bank tributary of the Pivka river before its ponor into the Postojna Cave. The brook is recharged by several temporary karst springs; their catchment area encompasses the Javorniki karst plateau and the upper part of the Pivka river basin, which has been confirmed by tracer tests (Habič 1989; Kogovšek 1999; Kogovšek et al. 1999). However, a small part of the Rakiški Stržen basin is developed on almost impermeable Quaternary deposits and Eocene flysch rocks. From this part of the basin, purified wastewater from the Central Wastewater Treatment Plant Postojna (15,000 PE), together with certain residual pollution and untreated wastewaters from the Rakitnik village, flows into the brook, which affects its quality. The objective of this study is to present in detail the hydrogeographic characteristics of the Rakiški Stržen brook and its quality.

The fieldwork comprised: (i) in situ measurements (a total of 46 measurements) of water temperature and dissolved oxygen concentration at three different points; and (ii) the sampling of water at the same points for subsequent simple chemical analysis (total and carbonate hardness, $\mathrm{pH}$, concentration of nitrate, nitrites, ammonium and phosphates) carried out using portable water analysis test kits. The study was carried out under different hydrological conditions in the period from mid-October 2013 to mid-June 2014. The first measuring point was located at the temporary Fužina karst spring (Figure 3), the second one was at the confluence of the Rakiški Stržen and the outflow from the wastewater treatment plant, and the third one was in the Rakiški Stržen, $100 \mathrm{~m}$ downstream from the Rakitnik village (Figure 1).

Meteorological and hydrological data was obtained from the Slovenian Environment Agency (ARSO). At a low water level on 16 October 2013, an automatic measuring device (Onset HOBO T and h Data Logger) was installed in the Rakiški Stržen under the bridge at Rakitnik. The device recorded the water level and temperature of the brook in half-hour intervals. All gathered hydrological data was used for the calculation of the water budget and the estimation of the Rakiški Stržen characteristic discharges over a longer period and during the abovementioned observation period.

The catchment area of the temporary karst springs recharging the Rakiški Stržen brook covers an area of $40 \mathrm{~km}^{2}$. Due to the fact that the brook often floods, the determination of its discharge characteristics is rather challenging. On the basis of simple hydrological assumptions and available discharge data of the Pivka river at different water-gauging stations, we estimated the mean discharge of the Rakiški Stržen for a longer period at $1.18 \mathrm{~m}^{3} / \mathrm{s}$. For the extraordinary wet hydrological year 2014, the discharge was estimated at $2.5 \mathrm{~m}^{3} / \mathrm{s}$. In future, serious efforts should be made to determine the stage-discharge curve of the Rakiški Stržen, which has to be calculated using continuous measurements of its water level and sporadic measurements of its discharge in different hydrological conditions.

The results of investigations (Habič 1985; 1989; Kogovšek 1999; Kogovšek et al. 1999; Kogovšek and Petrič 2004) show that for the adequate protection of the Rakiški Stržen appropriate water protection regulations should be implemented in the upper Pivka river basin and in the western part of the Javorniki karst plateau, where several potential polluters are present (untreated wastewaters from settlements, the Poček military training ground, the non-hazardous waste landfill Stara vas, traffic, etc.). Our measurements, conducted in the hydrological year 2014, did not reveal any pollution from the abovementioned potential polluters at the Fužina karst spring. However, pollution (from the waste landfill in particular) of the spring was confirmed in some of the previous investigations (Kogovšek 1996; Petrič and Šebela 2005). Nevertheless, the collection of waste waters from the landfill and their transport to the Central Wastewater Treatment Plant Postojna undoubtedly contributes to better water quality in the Fužina spring and other temporary karst springs, as well as in the Rakiški Stržen in general.

The results of the measurements of the physico-chemical properties of the Rakiški Stržen in the investigated period show that recorded concentrations of oxygen, nitrates, nitrites, ammonium and phos- 
phates in the samples are significantly influenced by temporary water conditions. During low waters, concentrations of the abovementioned parameters, with the exception of oxygen, were 10 times higher compared with the inundation period, which lasted for 130 days (i.e. more than a half of the investigated period). The highest water quality was recorded in the Fužina spring, where, with the exception of nitrates, no other sampled parameters were recorded. In terms of water quality, the other two sampling points are more problematical: one at the confluence, where waters from the central wastewater treatment plant flow, and the other at Rakitnik, where the sewage system is currently still under construction. Nevertheless, at these sampling points, with the exception of ammonium, the maximum permissible values for drinking water of other parameters were not exceeded (Poročilo o pitni vodi 2004-2009). The average concentrations of phosphates and ammonium at the outflow from the wastewater treatment plant measured within the framework of regular water quality monitoring (Poročilo o obratovalnem monitoringu ... 2015) are much higher than those measured in our study at the sampling point at the confluence. This means either that the concentrations of both parameters can drop significantly on the way from the outflow to the confluence, meaning that the self-cleaning capacity of the brook is rather sufficient, or that significant differences in measured values arise as a result of different methodologies and accuracy levels of analyses.

From the above we can conclude that the overloaded Central Wastewater Treatment Plant Postojna (primary and secondary treatment) overburdens the Rakiški Stržen brook. The wastewater purification effect for several parameters is low; concentrations of some parameters in the outflow are often exceeded. The wastewater treatment plant is currently under reconstruction. After the reconstruction is completed, its capacity will increase to $21,000 \mathrm{PE}$. The new plant will also provide advanced tertiary wastewater treatment involving phosphorus and nitrogen absorption, and disinfection of toxic microorganisms (Centralna čistilna naprava Postojna 2014). We expect that after the start-up of the new plant by the end of 2015 the quality of the Rakiški Stržen brook and consequently also of the Pivka river will significantly improve. 
